\title{
Growth of Oreochromis aureus fed with diets containing graded levels of coffee pulp and reared in two culture systems
}

\author{
J.B. Ulloa Rojas ${ }^{\mathrm{a}, *}$, J.A.J. Verreth ${ }^{\mathrm{b}}$ \\ ${ }^{a}$ Escuela de Ciencias Biológicas, Universidad Nacional, P.O. Box 86, Heredia 3000, Costa Rica \\ ${ }^{\mathrm{b}}$ Fish Culture and Fisheries Group, Wageningen Institute of Animal Science (WIAS), Wageningen University, \\ P.O Box 338, 6700 AH Wageningen, The Netherlands
}

Received 31 October 2001; received in revised form 11 April 2002; accepted 7 June 2002

\begin{abstract}
A study was conducted to compare growth and feed utilization of Oreochromis aureus fed graded levels of coffee pulp (CoP) and reared in aquaria or in pens. Diets contained 0, 130, 260 and $390 \mathrm{~g}$ $\mathrm{kg}^{-1}$ of oven-dried CoP. In aquaria, fish receiving increasing dietary CoP levels (from 0 to $390 \mathrm{~g}$ $\mathrm{kg}^{-1}$ ) showed a progressive reduction in final body weight, growth rate and protein efficiency ratio (PER) $(P<0.05)$. Feed conversion ratio $(\mathrm{FCR})$ was significantly higher at $390 \mathrm{~g} \mathrm{~kg}^{-1}$ dietary CoP. Dietary CoP reduced digestibility of dietary dry matter and carbohydrate. In pens, CoP inclusions led to reduced final weight, growth rate and PER but to a much smaller extent than in aquaria. Fish fed the diet with $130 \mathrm{~g} \mathrm{~kg}^{-1} \mathrm{CoP}$ had similar growth and feed utilization (PER and FCR) to those fed the control diet $(P>0.05)$. High dietary fibre levels together with the presence of antinutritional factors (ANFs) in CoP diets may explain why tilapia grew less and had lower feed utilization. Natural productivity of the pond could explain why results in pens were better than in aquaria. Results indicated that inclusion of CoP in tilapia diets might be limited to no more than $130 \mathrm{~g} \mathrm{~kg}^{-1}$ when fish are raised in earthen ponds and natural food is available.

(C) 2003 Elsevier Science B.V. All rights reserved.
\end{abstract}

Keywords: Tilapia; Coffee pulp; Aquaria; Pens; Fish nutrition; Oreochromis

* Corresponding author. Tel.: +506-2375230; fax: +506-237-6427.

E-mail address: julloa@una.ac.cr (J.B. Ulloa Rojas). 


\section{Introduction}

Coffee pulp (CoP) is the first residue obtained during processing of coffee berries, and it represents about $40 \%$ of the whole berry (on a wet basis) (Montero, 1992). In 1996, the CoP generated from producer countries (many tropical and subtropical areas) was estimated at about 22 million metric tones (MT) (estimation based on green production data, FAO, 1997). The CoP is a cost-free and readily available residue during 4 to 8 months along the harvesting season. The disposal of $\mathrm{CoP}$, however, generates a enormous problem and represents a potential pollution risk in producer countries. In this context, any attempt to recycle $\mathrm{CoP}$ in any more productive activity will alleviate its environmental impact. A possible potential use of $\mathrm{CoP}$ may be in the animal feeding industry by replacing mainly byproducts of vegetable origin. The $\mathrm{CoP}$ has been used in feeds for ruminants and monogastric animals with variable results (Braham and Bressani, 1979; Bressani and Braham, 1980). In fish, there are few records where the inclusion of $\mathrm{CoP}$ has been tested in a comprehensive and systematic way. These studies used one dietary level of CoP (e.g. $300 \mathrm{~g} \mathrm{~kg}^{-1}$ for common carp (Cyprinus carpio) and catfish (Clarias mossambicus) (Christensen, 1981) or did a laboratory study only (e.g. graded levels from 0 to $300 \mathrm{~g} \mathrm{~kg}^{-1}$ for catfish (Clarias isheriensis), Fagbenro and Arowosoge, 1991). In both studies, reduced growth and feed digestibility were found. The authors suggested that antinutritional factors (ANFs) in CoP were responsible for the reduced growth of the fish. However, that suggestion was not corroborated by the results of Ulloa and van Weerd (1997) who also found reduced growth and feed digestibility in tilapia (Oreochromis aureus) receiving graded levels of $\mathrm{CoP}(0,130$, 260 and $390 \mathrm{~g} \mathrm{~kg}^{-1}$ ), which had been pretreated with $\mathrm{NaOH}$ and contained strongly reduced levels of ANFs (caffeine, polyphenols and tannins). The latter study was also performed in aquaria. When CoP diets have been fed to fish reared in ponds, however, results differ from aquaria or tanks. For instance, $300 \mathrm{~g} \mathrm{~kg}^{-1}$ of CoP in supplementary feeds did not affect the growth of tilapia reared in extensive pond culture (García and Bayne, 1974; Bayne et al., 1976). Similar results were obtained when three CoP levels (0, 100 and $\left.200 \mathrm{~g} \mathrm{~kg}^{-1}\right)$ were fed to Cachamay (Colossoma $\mathrm{sp} . \times$ Piaractus sp.) reared in cages located in earthen ponds (Bautista et al., 1999). A possible explanation for the difference between culture systems is that in fishponds, the nutritionally negative effects of $\mathrm{CoP}$ may be masked by the available natural food. For this reason, a comparative experiment was designed to study this topic in more detail, and similar diets containing graded levels of $\mathrm{CoP}$ were fed to tilapia grown either in aquaria or in an earthen pond.

\section{Materials and methods}

Two feeding experiments were conducted: one in an experimental recirculation system (aquaria) and another in pens located in a fishpond.

\subsection{Diet preparation}

Fresh CoP was oven-dried for $24 \mathrm{~h}$ at $50{ }^{\circ} \mathrm{C}$, milled through a 1-mm diameter die and then analyzed for chemical composition (Table 1). In both experiments, four diets were 
Table 1

Chemical composition and content of antinutritional factors of oven-dried coffee pulp

\begin{tabular}{lllr}
\hline Components & $\left(\mathrm{g} \mathrm{kg}^{-1}\right)$ & Components & $\left(\mathrm{g} \mathrm{kg}^{-1}\right)$ \\
\hline True protein $^{\mathrm{a}}$ & 110 & Neutral detergent fibre & 585 \\
Crude protein $_{\text {Crude fat }}$ & 129 & Acid detergent fibre & 546 \\
Crude ash & 20 & Cellulose & 183 \\
Nitrogen-free extract $^{\mathrm{b}}$ & 62 & Polyphenols & 20 \\
Carbohydrate $^{\mathrm{c}}$ & 789 & Tannins & 7.4 \\
\hline
\end{tabular}

Data expressed on a dry matter basis.

a True protein method discriminates the amides from the crude protein method.

b Nitrogen-free extract refers to non-starch polysaccharides, starch and sugars.

c Carbohydrate refers to starch and sugars expressed as percentage of glucose.

tested which contained $0,130,260$ and $390 \mathrm{~g} \mathrm{~kg}^{-1}$, respectively, of oven-dried CoP. The diets were formulated to be approximately isonitrogenous (Table 2). All dry ingredients were mixed during 15 min before adding the lipids. Subsequently, mixing continued for another $15 \mathrm{~min}$. Next, water was added gradually until a desirable paste-like consistency was reached. This paste was forced through a 1-mm die using a meat grinder. Pellets were then dried for $16 \mathrm{~h}$ at $50{ }^{\circ} \mathrm{C}$. Finally, the feed was manually crumbled to pellet size. Feeds used in the aquaria study were supplemented with $1 \mathrm{~g} \mathrm{~kg}^{-1} \mathrm{Cr}_{2} \mathrm{O}_{3}$ for determination of apparent digestibility coefficients (ADC).

\subsection{Aquaria experiment}

There were four replicate aquaria per treatment. Each aquarium $(30 \times 50 \times 30 \mathrm{~cm})$ was stocked with $12 \mathrm{O}$. aureus fingerlings weighing between 5 and $8 \mathrm{~g}(7.12 \pm 0.78$ $($ mean \pm SE) $)$. Fish were fed to apparent satiation three times daily (9:00, 13:00 and 17:00 h) for 8 weeks. At the beginning and at the end of the experiment, samples of fish were taken for body composition analysis. Water quality was checked at the common outflow of aquaria in the recirculation system. Water temperature and dissolved oxygen were measured twice daily (8:00 and 17:00 h). Levels of $\mathrm{pH}$, nitrite and total ammonium were measured weekly. When necessary, by addition of tap water into the system (adjusting water flow), nitrite and total ammonia levels were maintained below 0.15 and $2.5 \mathrm{ppm}$, respectively, and dissolved oxygen above $3.5 \mathrm{ppm}$. The photoperiod was kept at $13 \mathrm{~h}$ day $^{-1}$ (from 6:00 to 19:00 h).

\subsection{Pen experiment}

In the pond trial, each pen $(4 \times 3 \times 2 \mathrm{~m}, 1 \mathrm{~m}$ water depth) was stocked with $20 O$. aureus fingerlings $\left(\approx 1.6\right.$ fish $\left.\mathrm{m}^{-3}\right)$ weighing between 9 and $12 \mathrm{~g}(10.28 \pm 1.31$ $($ mean $\pm \mathrm{SE})$ ). Pens were made of nylon knotless mesh (mesh size: $2.54 \mathrm{~cm})$. Each treatment had four replicates (20 pens). Fish were fed following the feeding table of Berzak (1992) two times daily (9:00 and 14:00 h) for 22 weeks. In the present study, daily feeding levels varied from $10 \%$ to $2 \%$ of body weight during the course of the experiment. In addition of the four treatments used (the same as in the aquaria experiment), a "no 
Table 2

Ingredient ( $\mathrm{g} \mathrm{kg}^{-1}$ as feed basis) and nutrient composition $\left(\mathrm{g} \mathrm{kg}^{-1}\right.$, dry matter) of diets containing different levels of coffee pulp (CoP) and used in the feeding trials (aquaria and pens) with $O$. aureus fingerlings

\begin{tabular}{|c|c|c|c|c|}
\hline & \multicolumn{4}{|c|}{ Diets $\left(\mathrm{g} \mathrm{kg}^{-1}\right)$} \\
\hline & D1 (0 CoP $)$ & D2 (130 CoP) & D3 (260 CoP) & D4 $(390 \mathrm{CoP})$ \\
\hline \multicolumn{5}{|l|}{ Ingredients } \\
\hline Fish meal & 420 & 420 & 430 & 450 \\
\hline Blood meal & 50 & 50 & 60 & 60 \\
\hline Soybean meal & 170 & 120 & 70 & 0 \\
\hline Coffee pulp & 0 & 130 & 260 & 390 \\
\hline Cassava starch & 310 & 220 & 130 & 30 \\
\hline Soybean oil & 20 & 20 & 20 & 20 \\
\hline Vitamins $^{\mathrm{a}}$ & 20 & 20 & 20 & 20 \\
\hline Sodium alginate & - & - & - & 20 \\
\hline Chromium oxide & 10 & 10 & 10 & 10 \\
\hline \multicolumn{5}{|l|}{ Nutrients } \\
\hline Moisture $\left(\mathrm{g} \mathrm{kg}^{-1}\right)$ & 47 & 67 & 60 & 47 \\
\hline Crude fat & 96 & 86 & 98 & 98 \\
\hline Crude fibre & 39 & 110 & 167 & 278 \\
\hline Crude ash & 116 & 126 & 136 & 155 \\
\hline Crude protein & 393 & 371 & 369 & 348 \\
\hline Nitrogen-free extract & 395 & 417 & 397 & 399 \\
\hline Carbohydrate $^{\mathrm{b}}$ & 356 & 306 & 230 & 121 \\
\hline Non-starch polyssacharides ${ }^{c}$ & 39 & 111 & 167 & 278 \\
\hline Digestible energy $\left(\mathrm{kJ} \mathrm{g}^{-1}\right)^{\mathrm{d}}$ & 12.7 & 11.6 & 11.1 & 9.7 \\
\hline
\end{tabular}

${ }^{\mathrm{a}}$ Amount/kg premix: $800000 \mathrm{IU}$ vitamin A; $200000 \mathrm{IU}$ vitamin $\mathrm{D} ; 10 \mathrm{~g}$ vitamin $\mathrm{E} ; 1 \mathrm{~g}$ vitamin $\mathrm{K} ; 2 \mathrm{~g}$ thiamin; 3 g riboflavin; $15 \mathrm{~g}$ pantothenate; $2 \mathrm{~g}$ pyridoxine; $2 \mathrm{mg} \mathrm{B} \mathrm{B}_{12} ; 20 \mathrm{~g}$ niacinamide; $0.5 \mathrm{~g}$ biotin; $200 \mathrm{~g}$ ascorbic acid; $1 \mathrm{~g}$ folic acid; $100 \mathrm{~g}$ choline.

b Carbohydrate refers to starch and sugars expressed as percentage of glucose.

c Nitrogen-free extract refers to non-starch polysaccharides, starch and sugars.

d Digestible energy: calculated according to nutrient digestible energy coefficients for Ictalurus punctatus, $14.6 \mathrm{~kJ} \mathrm{~g}^{-1}$ protein, $33.9 \mathrm{~kJ} \mathrm{~g}^{-1}$ fat and $10.5 \mathrm{~kJ} \mathrm{~g}^{-1}$ crude carbohydrate (NRC, 1977).

feeding" treatment was included in the study to determine the relative contribution of natural food to the fish. Every 2 weeks, all fish were weighed to adjust feeding rates.

\subsection{Parameters measured and chemical analyses}

Growth (relative growth rate of metabolic weight: $\mathrm{RGR}_{\mathrm{m}}$, daily weight gain: $\mathrm{DWG}$ ), feed utilization parameters (feed conversion ratio: FCR, protein efficiency ratio: PER) and survival $(\%)$ were calculated for each treatment and both culture systems.

Chemical analyses of CoP, diets and fish were done by standard procedures. Caffeine was determined according to Morris (1973). Polyphenols and tannins were extracted from $\mathrm{CoP}$ and diet samples with a methanol/water solution $(70 \% \mathrm{v} / \mathrm{v})$ by reflux for $2 \mathrm{~h}$ at boiling temperature, and their concentration were determined using the Folin-Ciocalteu reagent according to Slinkard and Singleton (1977) and AOAC (1990), respectively. Total utilizable carbohydrate was measured by the Anthrone method (Osborne and Voogt, 1986). To determine true protein levels in CoP, samples were boiled in water to dissolve 
amides. After boiling, the protein was precipitated in the presence of copper (II) hydroxide and subsequently separated from the dissolved amides by filtration (Stutzer and Barstein, 1900). The N content of the filtrate was determined according to the Kjedahl method. Cellulose was determined using the procedure of Meites (1963). The other chemical components (neutral and acid detergent fibre: NDF and ADF, crude protein, crude fat, crude ash) were analyzed according to AOAC (1990).

\subsection{Statistical analysis}

Data from the aquaria trial were analyzed by a covariance analysis with initial weight as a covariant and dietary treatment as class variable. Data from the pen trial were analyzed by a one-way ANOVA. Treatment means (from replicates) were compared by the LSD test with $95 \%$ confidence intervals. The statistical analysis was done using the software STATGRAPHICS PLUS STATISTICAL GRAPHICS SYSTEM 7.1 (Manugistics and Statistical Graphics, 1993).

\section{Results and discussion}

\subsection{Aquaria experiment}

In the aquaria trial, final body weight, growth rate and PER decreased with increasing dietary CoP levels from 0 to $390 \mathrm{~g} \mathrm{~kg}^{-1}(P<0.05)$. The FCR was significantly higher only at $390 \mathrm{~g} \mathrm{~kg}^{-1}$ of dietary CoP (Table 3). The high survival rate (above 92\%) found with $\mathrm{CoP}$ diets suggests that $O$. aureus fingerlings can tolerate relatively high levels of $\mathrm{CoP}$ substances (caffeine, polyphenols, tannins and high potassium levels), which are

Table 3

Average values of body weight, relative growth rate of metabolic weight ( $\left.\mathrm{RGR}_{\mathrm{m}}\right)$, feed conversion ratio (FCR), protein efficiency ratio (PER), feed intake, and diet and nutrient digestibility of fingerlings $O$. aureus fed different dietary coffee pulp (CoP) levels and reared in an aquaria system (means \pm standard error)

\begin{tabular}{|c|c|c|c|c|}
\hline & \multicolumn{4}{|c|}{ Diets $\left(\mathrm{g} \mathrm{kg}^{-1}\right)$} \\
\hline & $0 \mathrm{CoP}$ & $130 \mathrm{CoP}$ & $260 \mathrm{CoP}$ & $390 \mathrm{CoP}$ \\
\hline \multicolumn{5}{|l|}{ Variables } \\
\hline Initial body weight (g) & $7.2 \pm 0.05^{\mathrm{a}}$ & $5.4 \pm 0.04^{\mathrm{b}}$ & $6.2 \pm 0.03^{\mathrm{b}}$ & $7.7 \pm 0.05^{\mathrm{a}}$ \\
\hline Final body weight $(\mathrm{g})$ & $45.0 \pm 0.65^{\mathrm{a}}$ & $29.4 \pm 0.95^{\mathrm{b}}$ & $15.5 \pm 1.05^{\mathrm{c}}$ & $7.9 \pm 0.87^{\mathrm{d}}$ \\
\hline $\mathrm{RGR}_{\mathrm{m}}\left(\mathrm{g} / \mathrm{kg}^{0.8} /\right.$ day $)$ & $17.2 \pm 0.12^{\mathrm{a}}$ & $12.6 \pm 0.29^{\mathrm{b}}$ & $5.8 \pm 0.61^{\mathrm{c}}$ & $1.6 \pm 0.51^{\mathrm{d}}$ \\
\hline FCR & $1.2 \pm 0.05^{\mathrm{a}}$ & $1.3 \pm 0.29^{\mathrm{a}}$ & $2.0 \pm 0.35^{\mathrm{a}}$ & $4.3 \pm 0.15^{\mathrm{b}}$ \\
\hline PER & $2.1 \pm 0.07^{\mathrm{a}}$ & $2.0 \pm 0.15^{\mathrm{a}}$ & $1.4 \pm 0.11^{\mathrm{b}}$ & $0.7 \pm 0.03^{\mathrm{c}}$ \\
\hline Feed intake ( $\mathrm{g} /$ fish/day) & $0.83 \pm 0.14^{\mathrm{a}}$ & $0.54 \pm 0.05^{\mathrm{b}}$ & $0.28 \pm 0.05^{\mathrm{c}}$ & $0.1 \pm 0.01^{\mathrm{d}}$ \\
\hline \multicolumn{5}{|c|}{ Digestibility $\left(g \mathrm{~kg}^{-1}\right.$, dry matter) } \\
\hline Dry matter & $740 \pm 0.11^{\mathrm{a}}$ & $682 \pm 1.05^{\mathrm{ab}}$ & $621 \pm 1.15^{\mathrm{b}}$ & $624 \pm 0.56^{\mathrm{b}}$ \\
\hline Protein & $827 \pm 0.25^{\mathrm{a}}$ & $822 \pm 0.89^{\mathrm{a}}$ & $834 \pm 1.15^{\mathrm{a}}$ & $841 \pm 1.28^{\mathrm{a}}$ \\
\hline Carbohydrate & $874 \pm 0.98^{\mathrm{a}}$ & $882 \pm 0.935^{\mathrm{a}}$ & $632 \pm 0.67^{\mathrm{c}}$ & $610 \pm 0.45^{\mathrm{c}}$ \\
\hline
\end{tabular}

\footnotetext{
${ }^{\text {abcd }}$ Means in the same line with no letters in common differ statistically $(P<0.05)$.
} 
suspected to cause high mortality in some domestic animals, including poultry, rats and turkeys (Bressani et al., 1973; Gómez et al., 1985; Donkoh et al., 1988). The drastic reduction in feed intake at higher dietary CoP levels may be associated with polyphenols and tannins, which are known to produce a bitter taste in diets for domestics animals (Bressani et al., 1975; Bressani and Braham, 1980; de Rozo et al., 1985). During the feeding period, it was observed that the fish often rejected the pellets from diets with higher CoP levels (260 and especially at $390 \mathrm{~g} \mathrm{~kg}^{-1}$ ), which may indicate that the taste of those feeds affected feed intake negatively. Another possible explanation for reduced feed intake might be the increased level of undigestible fibre in those diets.

The high dietary fibre levels together with the presence of ANFs (high $\mathrm{K}$ level, polyphenols, tannins, caffeine) may explain why tilapia grew less and had a lower feed utilization with CoP diets. These factors could interfere with nutrient availability and digestion by fish but also could induce toxicity (high $\mathrm{K}$ level) and low feed acceptability (Bressani and Braham, 1980; de Rozo et al., 1985; Vélez et al., 1985; Mehansho et al., 1987). Protein digestibility was not affected by the inclusion of CoP in diets, but dietary dry matter and carbohydrate digestibility of tilapia were significantly reduced in fish fed diets containing CoP (Table 3). These negative effects could possibly be attributed to reduced availability of carbohydrate and/or to increased levels of fibre in diets. Tannins can also interact with polysaccharides making them unavailable to the fish (MuellerHarvey and McAllan, 1992). Obviously, if higher CoP levels are used in fish feeds, these factors should be reduced or destroyed.

\subsection{Pen experiment}

In pens, the reductions in final weight, growth rate and PER attributable to $\mathrm{CoP}$ were much lower than in aquaria. Fish fed the diet with $130 \mathrm{~g} \mathrm{~kg}^{-1} \mathrm{CoP}$ had similar growth and feed utilization compared to those fed the control diet $(P>0.05)$ (Table 4; Fig. 1). The results in pens concur with findings of Bayne et al. (1976) with tilapia and of Bautista et al. (1999) with Cachamay (Colossoma sp. $\times$ Piaractus sp.), who found similar growth in fish fed diets containing CoP and control diets. The amount of feed that could be fed to the fish decreased with increasing levels of CoP in the diet $\left(260\right.$ and $\left.390 \mathrm{~g} \mathrm{~kg}^{-1}\right)$. This is in

Table 4

Average values of body weight, relative growth rate of metabolic weight $\left(\mathrm{RGR}_{\mathrm{m}}\right)$, feed conversion ratio (FCR), protein efficiency ratio (PER) and feed given of fingerlings $O$. aureus fed with different dietary coffee pulp $(\mathrm{CoP})$ levels and reared in pens maintained in an earthen pond (means \pm standard error)

\begin{tabular}{|c|c|c|c|c|c|}
\hline \multirow[t]{2}{*}{ Variables } & \multicolumn{5}{|l|}{ Diets $\left(\mathrm{g} \mathrm{kg}^{-1}\right)$} \\
\hline & $0 \mathrm{CoP}$ & $130 \mathrm{CoP}$ & $260 \mathrm{CoP}$ & $390 \mathrm{CoP}$ & No feed \\
\hline Initial body weight (g) & $10.0 \pm 0.21^{\mathrm{a}}$ & $10.5 \pm 0.34^{\mathrm{a}}$ & $10.0 \pm 0.23^{\mathrm{a}}$ & $10.8 \pm 0.59^{\mathrm{a}}$ & $10.0 \pm 0.55^{\mathrm{a}}$ \\
\hline Final body weight (g) & $174.2 \pm 1.45^{\mathrm{a}}$ & $176.3 \pm 2.01^{\mathrm{a}}$ & $144.2 \pm 1.44^{\mathrm{b}}$ & $98.0 \pm 0.56^{\mathrm{c}}$ & $24.9 \pm 0.65^{\mathrm{d}}$ \\
\hline $\mathrm{RGR}_{\mathrm{m}}\left(\mathrm{g} / \mathrm{kg}^{0.8} /\right.$ day $)$ & $15.9 \pm 0.12^{\mathrm{a}}$ & $15.9 \pm 0.25^{\mathrm{a}}$ & $14.4 \pm 0.55^{\mathrm{ab}}$ & $10.7 \pm 0.67^{\mathrm{b}}$ & $3.2 \pm 0.11^{\mathrm{c}}$ \\
\hline FCR & $1.7 \pm 0.08^{\mathrm{a}}$ & $1.8 \pm 0.08^{\mathrm{a}}$ & $1.8 \pm 0.05^{\mathrm{a}}$ & $2.4 \pm 0.09^{\mathrm{b}}$ & - \\
\hline PER & $1.5 \pm 0.15^{\mathrm{a}}$ & $1.4 \pm 0.06^{\mathrm{a}}$ & $1.5 \pm 0.21^{\mathrm{a}}$ & $1.1 \pm 0.1^{\mathrm{b}}$ & - \\
\hline Feed given (g/fish/day) & $2.1 \pm 0.22^{\mathrm{a}}$ & $2.3 \pm 0.13^{\mathrm{a}}$ & $1.8 \pm 0.08^{b}$ & $1.6 \pm 0.17^{\mathrm{b}}$ & - \\
\hline
\end{tabular}

${ }^{\mathrm{abcd}}$ Means in the same line with no letters in common differ statistically $(P<0.05)$. 




Fig. 1. Reduction in final weight, relative growth rate of metabolic weight $\left(\mathrm{RGR}_{\mathrm{m}}\right)$ and protein efficiency ratio (PER) of $O$. aureus fed diets containing different coffee pulp (CoP) levels, and reared in aquaria and pens.

accordance with the results from aquaria trial and suggests indirectly that the palatability of diets high in CoP (and high in fibre content) may have been a main factor limiting feed intake and growth of fish.

Contrary to results in aquaria trial, in pens, tilapia growth was not altered by dietary CoP levels between 0 and $130 \mathrm{~g} \mathrm{~kg}^{-1}$. The natural productivity of the pond could explain why results in pens differed from those in aquaria. In the no feeding treatment, natural food supported fish growth for 2 weeks and after that period, when the fish reached about $25 \mathrm{~g}$, the available natural food only was enough to maintain fish weight for the remaining experimental period. Assuming that the same amount of natural food was available to the fish in the other treatments, the higher FCR values found in pens could result from overfeeding. Our results have shown that the potential inclusion of $\mathrm{CoP}$ in tilapia diets may be limited up to $130 \mathrm{~g} \mathrm{~kg}^{-1}$ when fish are raised in earthen ponds and natural food is available.

Our findings may have an especial relevance in those areas where CoP is readily available, and fish culture is practiced in extensive and/or semi-intensive conditions using omnivorous and/or herbivorous fish species such as Oreochromis, Colossoma and different carp species. If these fish species are reared in earthen ponds or pens instead of concrete tanks or raceways, CoP will have a potential as a feed ingredient in fish diets as it was found in our study. In contrast with cereal by-products, however, the high moisture content and the presence of ANFs in CoP will to some extent limit its potential use in fish feeds. One important consideration on this context will be the processing cost to produce CoP meal that may be high because of the extra cost of drying. Unfortunately, up to date, there is no reported data estimating this cost at an industrial scale, which could allow a more precise cost comparison with other commercial feed ingredients of similar origin. 


\section{Acknowledgements}

We are grateful to the Program UNA-LUW/Ciencias Acuáticas, Escuela Ciencias Biológicas, Universidad Nacional, Costa Rica and Fish Culture and Fisheries Group, Wageningen University and Research Center, The Netherlands, and also to the Costa Rican Coffee Research Center (CICAFE) for the analysis of caffeine.

\section{References}

Association of Official Analytical Chemists (AOAC), 1990. In: Helrich, K. (Ed.), Official Methods of Analysis of the Association of Official Analytical Chemists. Food Composition; Additives; Natural Contaminants. Virginia, USA, $1298 \mathrm{pp}$.

Bautista, E., Useche, M., Pérez, F., Linares, F., 1999. Utilización de la pulpa de café ensilada y deshidratada en la alimentación de Cachamay (Colossoma $\times$ Piaractus). Ramírez, J. (Ed.), Pulpa de café ensilada. Producción, caracterización, y utilización en alimentación animal. LitoFormas, Estado del Táchira, Venezuela, pp. $109-135$.

Bayne, D., Dunseth, D., García, C., 1976. Supplemental feeds containing coffee pulp for rearing Tilapia in Central America. Aquaculture 7, 133-146.

Berzak, O., 1992. Informe de Consultoría sobre cultivo intensivo de Tilapia (Costa Rica, Guatemala). PRADEPESCA (Convenio ALA/90-9). Ciudad Panamá, Panamá, 47 pp.

Braham, J., Bressani, R., 1979. Coffee pulp. Composition, Technology, and Utilization. Braham, J., Bressani, R. (eds.). International Development Research Centre (IDRC), Ottawa, Canada, 95 pp.

Bressani, R., Braham, J. 1980. Utilization of coffee pulp as animal feed. In: ASIC (Ed.), Proceedings of the 9th International Scientific Colloquium on Coffee. ASIC, London, UK, pp. 303-323.

Bressani, R., Estrada, E., Elías, L., Jarquín, R., Urrutia, L., 1973. Pulpa y pergamino de café: IV. Efecto de la pulpa de café deshidratada en la dieta de ratas y pollos. Turrialba 23, 403-410.

Bressani, R., Cabezas, M., Jarquín, R., Murillo, B. 1975. The use of coffee processing waste as animal feed. In: Tropical Products Institute (Ed.), Proceedings of the Conference on Animal Feeds of Tropical and Subtropical Origin. Tropical Products Institute, London, UK, pp. 107-117.

Christensen, M., 1981. Preliminary tests on the suitability of coffee pulp in the diets of common carp (Cyprinus carpio L.) and catfish (Clarias mossambicus Peters). Aquaculture 25, 235-242.

De Rozo, M., Vélez, J., García, L., 1985. Efecto de los polifenoles de la pulpa de café en la absorción de hierro. Arch. Latinoam. Nutr. 35, 287-296.

Donkoh, A., Atuahene, C., Kese, A., Mensah-Asante, B., 1988. The nutritional value of dried coffee pulp (DCP) in broiler chickens' diets. Anim. Feed Sci. Technol. 22, 139-146.

Fagbenro, O., Arowosoge, A., 1991. Growth response and nutrient digestibility by Clarias isheriensis (Sydenham, 1980) fed varying levels of dietary coffee pulp as replacement for maize in low-cost diets. Bioresour. Technol. 37, 253-258.

Food and Agricultural Organization (FAO), 1997. Production Yearbook. Vol. 50. FAO Statistics Series No. 135. Rome, Italy, $172 \mathrm{pp}$.

García, C., Bayne, D., 1974. Cultivo de Tilapia aurea (Steindachner) en corrales con alimentación suplementaria. FAO, Carpas/6/74/SE 9, Report No. 248. Montevideo, 19 pp.

Gómez, R., Bendaña, G., González, J., Braham, J., Bressani, R., 1985. Relación entre los niveles de inclusión de pulpa de café y el contenido proteínico en raciones para animales monogástricos. Arch. Latinoam. Nutr. 35, $423-436$.

Mehansho, H., Butler, L., Carlson, D., 1987. Dietary tannins and salivary proline-rich proteins: interactions, induction and defense mechanisms. Annu. Rev. Nutr. 7, 423-440.

Meites, L., 1963. Handbook of Analytical Chemistry. Chapter 13: Analysis of Technical Materials, pp. $13-161$. McGraw Hill, USA.

Mueller-Harvey, I., McAllan, A., 1992. Tannins. Their biochemistry and nutritional properties. Adv. Plant Cell Biochem. Biotechnol. 1, pp. 151-217. 
Montero, M., 1992. Producción de abono orgánico de pulpa de café. CICAFE, ICAFE, San José, Costa Rica, $15 \mathrm{pp}$.

Morris, B., 1973. The Chemical Analysis of Foods and Food Products. Robert Kriger Publishing, New York, USA. Reprint of 3rd edition, $970 \mathrm{pp}$.

National Research Council (NRC), 1977. Nutrient Requirement of Warmwater Fishes. National Academy of Science, Washington, DC, USA, $77 \mathrm{pp}$

Osborne, D., Voogt, P., 1986. Análisis de los nutrientes de los alimentos. Editorial Acribia, Zaragoza, España, $258 \mathrm{pp}$.

Slinkard, K., Singleton, V., 1977. Total phenol analysis: automation and comparison with manual methods. Am. J. Enol. Vitic. 28, 49-55.

Stutzer, N., Barstein, F., 1900. Landwirtschaftlichesversuchstat 54, 327.

Ulloa, J., van Weerd, H., 1997. The growth and feed utilization of Oreochromis aureus fingerlings fed diets with various coffee pulp levels. In: Fitzsimmons, K. (Ed.), Proceedings from the Fourth International Symposium on Tilapia in Aquaculture, vol. 1. NRAES-106, Orlando, USA, pp. 40-49.

Vélez, A., García, L., de Rozo, M., 1985. Interacción in vitro entre los polifenoles de la pulpa de café y algunas proteínas. Arch. Latinoam. Nutr. 35, 297-301. 